\title{
Quality Function Deployment: An Application on Determining the Quality Factors in Higher Education
}

\author{
Mehmet A. Gündüz
}

\begin{abstract}
Quality Function Deployment (QFD) is a method developed in the 1970's in Japan by Dr. Yoji Akao and with later contributions of Shigeru Mizuno. QFD is adopted all over the world following a number of successful applications in Japan and has been applied very widely until today. This term has been translated to English as "Quality Function Deployment" from original Japanese name "Ten Kai Hin Shits Ki No". The most basic purpose of QFD is to design the functions which product performs according to the needs and requirements of customers. The aim of this study is to apply QFD in a university in Turkey in terms of service quality in higher education in order to determine needs and requirements of internal and external customers consisting of university academic and administrative staff, students and students' families. The House of Quality tool is used to assess the Voice of Customer about the quality of higher education. The study is based on an empirical analysis on a survey which was conducted among 100 students, 30 students' family members, and 30 academic and administrative staff of a university in Konya, Turkey. The analysis shows that student family members have the highest importance scores among the stakeholders and competence of academic staff has the highest scores among the quality factors.
\end{abstract}

Index Terms-Quality function deployment, service quality, higher education.

\section{INTRODUCTION}

Quality Function Deployment (QFD) is a method which was firstly used in late 1960's in Kobe shipyards of Japan. Later QFD was methodically developed in the 1970's by Yoji Akao and with later contributions of Shigeru Mizuno [1]. After a number of successful applications in Japan QFD is adopted all over and has been applied very widely until today in an environment of overruling intense competition and globalization. QFD is a simple but effective process which customer-focused entities needs in this environment. According to the definition made by Akao and Mizuno QFD is a quality system which ensures customer satisfaction within a framework of Total Quality Management [2]. The term of "Quality Function Deployment" has been translated to English as from original Japanese name "Ten Kai Hin Shits Ki No" [3]. The most basic purpose of QFD is to design the functions which product performs according to the needs and requirements of customers.

The first article about QFD was published in the journal named "Standardization and Quality Control" with the title "Development and Quality Assurance of New Products: A

Manuscript received October 10, 2015; revised February 20, 2016. This work was supported in part by KTO Karatay University.

M. A. Gunduz is with KTO Karatay University, Karatay, Konya, Turkey (e-mail: akifgunduz@karatay.edu.tr).
System of Quality Deployment" by Akao in 1972 [4]. Nonetheless QFD was firstly used for the production of super tankers by Mitsubishi Heavy Industries in the Kobe shipyard following the company's support request from Japanese government for the purpose of improvement of complex production logistics. And with the contribution of government and numerous instructors QFD was developed as a system which provides each phase of production to be intended for satisfying one customer request. In these shipyard studies the term of "Quality Deployment" was firstly emerged as its original Japanese name "Hinshitsu Tenkai" [5]. In the early 1980s, Akao associated QFD with value engineering and cost deployment tools and value engineering showed the direction to define the function of a product for researchers [6]. Following these developments, Toyota was among the companies that applied QFD successfully as they managed to reduce cost, product innovation and launch times [6]. These successful applications of Toyota resulted as drawing attention of Western companies. First QFD application outside of Japan was carried out by Xerox Corporation in 1984 [7]. And the first application of QFD in Turkey was about production of dishwashers by Arçelik in 1994 [8].

Functionally, QFD is a technique which is used to determine characteristics and attributions of products and services by fully understanding customer requirements and expectations and converting them into quantitative assessments. Akao characterizes QFD as it transforms qualitative customer demands to quantitative parameters and uses them to achieve the design quality as subsystems, components and finally dimensions of production process' specific elements [3]. The basic purpose of QFD is to design functions carried out by the product in accordance with customer needs and wants. So, in a sense, it realizes the customer requests' effects on quality. In this aspect it has the ability to convert voice of customer to production [9]. The process of converting voice of customer to product design makes it possible to distinguish necessary and unnecessary functions and attributions from the customer perspective. In this way the product is developed whereas ensuring the meeting or exceeding of customer expectations [10].

The basic premise of QFD technique is customer demands. Also it was founded on the concept of Company Wide Quality Control (CWQC). CWQC philosophy has the characteristic of being customer-focused and being process-oriented rather than cross-functional management and product oriented. From this perspective QFD is used as a management tool used for modelling the dynamics of the design process [11], [12].

QFD technique is widely known as House of Quality (HoQ) 
[11]. The formation of a house shape with a roof by the QFD matrices is meant by the "house" term. HoQ-the main tool of QFD implementation- is a set of matrices which is used for comparing customer requirements, product and quality characteristics between each other and themselves on the basis of objective criteria, and determining positive or negative correlations between them by associating customer needs and wants with quality characteristics determined to meet these needs and wants [13], [14]. This set of matrices analyzes customer needs and wants in detail, and translates them into the language of design [15]. HoQ is the part of QFD which fulfills the function of transforming the product and service that customer wants to purchase into design by focusing core business skills with production and marketing purposes [16]. QFD matrices were firstly used by Shigeru Mizuno and Yasushi Furukawa in the Kobe shipyard studies with Mitsubishi Heavy Industries [17] (see Fig. 1).

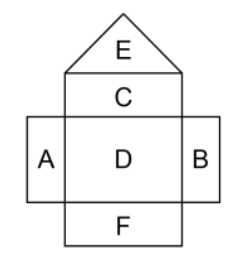

Fig. 1. House of quality.

HoQ consists of 6 main sections. These parts are also as shown in Fig. 1: (A) voice of customer, (B) customer satisfaction level, (C) technical specifications, (D) relationship matrix between voice of customer and technical specifications, (E) correlations between technical specifications, (F) comparison of competitors and target values [18]. The section of HoQ corresponding voice of customer is the answer of "What?" question and the section corresponding technical specifications is the answer of "How?" question [19].

\section{RESEARCH GOAL}

The aim of this study is to apply QFD in a university in Turkey in terms of service quality in higher education in order to determine needs and requirements of internal and external customers consisting of university academic and administrative staff, students and students' families. HoQ tool of QFD which is used for identifying voice of customer is utilized for identifying stakeholders' needs and wants. The stakeholder term is used in this study to signify internal and external customers of university-academic and administrative staff, students and students' families. As well as utilization of QFD's service sector applications by the researchers as a study field in recent years, worldwide higher education practices have accelerated recently. However, studies conducted in this field in Turkey is very limited. The only work that can be shown as an example was carried out by Çavdır and Ece [20].

\section{RESEARCH METHOD}

In this study voice of customer section of HoQ is utilized in the scale of a university in Turkey to determine needs and requirements of stakeholders consisting of university academic and administrative staff, students and students' families. One of the most important steps of QFD implementation in an organization is defining current and potential customers/stakeholders and identifying their needs and wants correctly due to QFD's customer-focused aspect. The university which the study was carried out, has 195 academic staff, 107 administrative staff, and 1961 bachelor students in the spring term of 2014-2015 academic year. A sample is chosen with quota sampling method in order to represent university's stakeholder distribution and the study is based on an empirical analysis on a survey which was conducted among 100 students, 30 students' family members, and 30 academic and administrative staff (see Fig. 2).

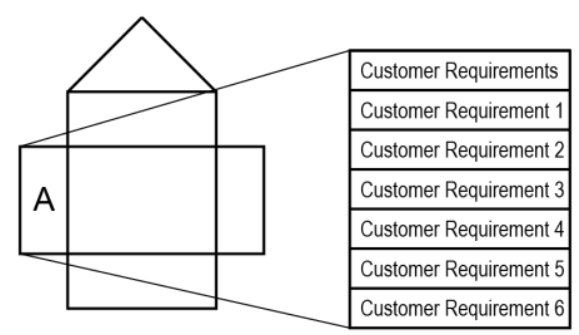

Fig. 2. Voice of customer section in HoQ.

The section of voice of customer corresponding to the stakeholders' requirements in the HoQ is shown in Fig. 2. In the stage of identifying stakeholders' requirements, because of stakeholders' non-organized opinion explanations, the requirements can be scattered. These requirements may be related to different components of the different elements of the education service. Therefore, these needs and wants have been grouped together in a way associated with each other. This grouping helps to address stakeholder requirements in a specific order in identification of technical specifications stage of HoQ creation. At this stage, with data collected from the sample consists of internal and external customers, importance level of needs and wants are determined. Importance levels are scaled from 1 to 5 . The number 1 on the scale stands for "not important at all" and the number 5 stands for "extremely important". Importance level of a requirement is calculated by the sum of each stakeholder's importance answer divided by the related stakeholder group sample size (see Fig. 3).

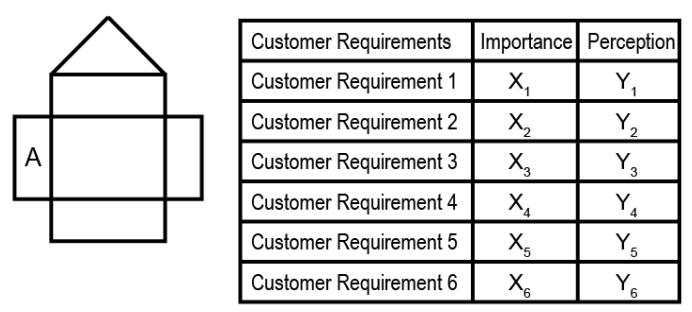

Fig. 3. Rank of importance and perception levels.

Following the identification of importance levels of stakeholders' requirements, the perception levels of the university's education related to requirements are measured. Perception levels are scaled from 1 to 5 . The number 1 on the scale stands for "not good at all" and the number 5 stands for "extremely good"(see Table I-Table V).

Stakeholders' expectations regarding the determined elements of higher educational quality are classified in the following titles. This classification is employed from studies of Çavdar and Ece [20], Cinpolat [21] and Hacettepe 
University Strategic Plan [22];

1) Physical qualification

2) Academic qualification

3) Access qualification

Stakeholder requirements grouped in physical qualification title are: campus landscape design, buildings and classrooms, library, labs, canteen, refectory, stationery, security, cleanliness, maintenance, sports facilities, conference rooms, and air conditioning. Stakeholder requirements grouped in academic qualification title are: academic staff qualification, academic staff quantity, student admission requirements, level of student achievement, academic counseling, comprehensiveness of curriculum, timeliness of curriculum, coherence of curriculum, appropriateness of curriculum for professional career, relation of curriculum with education program, foreign language education, measurement and evaluation, discipline, learning materials and auxiliary equipment, student council, student clubs, scientific/professional events and attendance of students. Stakeholder requirements grouped in access qualification title are: transportation, banks and ATMs, internet connection, administrative staff numerical competence, data processing services, student affairs services, information and access, automation system, social and cultural events.

TABLE I: IMPORTANCE AND PERCEPTION SCALES

\begin{tabular}{llll}
\hline \hline $\begin{array}{l}\text { Importance } \\
\text { Level }\end{array}$ & Description & $\begin{array}{l}\text { Perception } \\
\text { Level }\end{array}$ & Description \\
\hline 1 & $\begin{array}{l}\text { Not important at } \\
\text { all }\end{array}$ & 1 & Not good at all \\
2 & $\begin{array}{l}\text { Not too important } \\
\text { Somewhat }\end{array}$ & 2 & Not too good \\
3 & important & 3 & Somewhat good \\
4 & Very important & 4 & Very good \\
5 & Extremely & 5 & Extremely good \\
\hline \hline
\end{tabular}

\section{FINDINGS}

The data obtained from participants of each stakeholder group are analyzed with IBM SPSS Statistics 20.0. Mean importance scores of stakeholder groups are given below.

Student family has the highest importance means among stakeholder groups for all three quality dimensions. Besides academic staff has the lowest mean of physical qualification and access qualification importance level scores. Conversely, administrative staff has the lowest mean of academic qualification importance scores.

Additionally, mean perception levels of stakeholder groups according to quality dimensions are given below.

TABLE II: MEAN IMPORTANCE LEVELS OF STAKEHOLDERS

\begin{tabular}{lccll}
\hline \hline & Student & $\begin{array}{l}\text { Student } \\
\text { family }\end{array}$ & $\begin{array}{l}\text { Academic } \\
\text { staff }\end{array}$ & $\begin{array}{l}\text { Administrative } \\
\text { staff }\end{array}$ \\
\hline $\begin{array}{l}\text { Physical } \\
\text { qualification }\end{array}$ & 4,24 & 4,44 & 4,15 & 4,24 \\
$\begin{array}{l}\text { Academic } \\
\text { qualification }\end{array}$ & 4,28 & 4,54 & 4,33 & 4,23 \\
$\begin{array}{l}\text { Access } \\
\text { qualification }\end{array}$ & 4,25 & 4,40 & 4,10 & 4,26 \\
\hline \hline
\end{tabular}

TABLE III: PERCEPTION LEVELS OF STAKEHOLDERS

\begin{tabular}{lllll}
\hline \hline & Student & $\begin{array}{l}\text { Student } \\
\text { family }\end{array}$ & $\begin{array}{l}\text { Academic } \\
\text { staff }\end{array}$ & $\begin{array}{l}\text { Administrative } \\
\text { staff }\end{array}$ \\
\hline $\begin{array}{l}\text { Physical } \\
\text { qualification } \\
\text { Academic } \\
\text { qualification } \\
\begin{array}{l}\text { Access } \\
\text { qualification }\end{array}\end{array}$ & 3,06 & 2,85 & 3,21 & 3,31 \\
\hline \hline
\end{tabular}

As the results show, student families have the lowest perception mean about physical qualification dimension of the university which the survey was conducted. Contrarily, administrative staff has the highest mean of physical qualification perception. The perception of academic qualification is the same for student families and student who simultaneously have the lowest mean for this quality dimension. Again, administrative staff has the highest mean of academic qualification and also access qualification which has the lowest mean for students.

TABLE IV: DESCRIPTIVE STATISTICS OF PHYSICAL QUALIFICATION IMPORTANCE

\begin{tabular}{lllll}
\hline \multicolumn{5}{c}{ IMPORTANCE } \\
& $M$ & SD & Min. & Max. \\
\hline Student & 4,2430 &, 50009 & 1,62 & 5,00 \\
Student family & 4,4396 &, 55062 & 3,54 & 5,00 \\
Academic staff & 4,1469 &, 55211 & 2,69 & 5,00 \\
Administrative staff & 4,2404 &, 20326 & 3,85 & 4,46 \\
Total & 4,2354 &, 49730 & 1,62 & 5,00 \\
\hline \hline
\end{tabular}

There is no significant difference between the groups in physical qualification according to the analysis of variance. However, it is observed that administrative staff have the smallest deviation.

TABLE V: DESCRIPTIVE STATISTICS OF ACADEMIC QUALIFICATION IMPORTANCE

\begin{tabular}{lllll}
\hline \hline & $M$ & SD & Min. & Max. \\
\hline Student & 4,4749 &, 53331 & 1,08 & 5,00 \\
Student family & 4,6667 &, 24533 & 4,33 & 4,92 \\
Academic staff & 4,5076 &, 33817 & 3,83 & 5,00 \\
Administrative staff & 4,4583 &, 38576 & 3,92 & 5,00 \\
Total & 4,4942 &, 46801 & 1,08 & 5,00 \\
\hline \hline
\end{tabular}

No significant difference between groups is found for academic qualification importance level of stakeholders. However, importance of academic qualification has the highest total mean among three quality dimensions.

Importance of access qualification has the lowest total means among the quality dimensions. Again no significant difference between stakeholder groups is found.

TABLE V: DESCRIPTIVE STATISTICS OF ACCESS QUALIFICATION IMPORTANCE

\begin{tabular}{lllll}
\hline \hline & $M$ & SD & Min. & Max. \\
\hline Student & 3,9506 &, 50634 & 1,56 & 4,89 \\
Student family & 4,2540 &, 40427 & 3,56 & 4,67 \\
Academic staff & 3,9141 &, 57779 & 2,44 & 5,00 \\
Administrative staff & 3,9444 &, 42414 & 3,00 & 4,22 \\
Total & 3,9633 &, 51053 & 1,56 & 5,00 \\
\hline \hline
\end{tabular}

Factors which have the highest importance means among 
physical qualification are respectively labs, air conditioning and library. Stationery, canteen and refectory have the lowest means.

For the academic qualification dimension, factors that are considered to be most important are academic staff qualification, timeliness of curriculum, and appropriateness of curriculum for professional career. Contrarily, student clubs and student council are considered to be least important among academic qualification factors.

The factors belong to the dimension of access qualification have about the same importance levels. On the other hand, automation system and student affairs are the most important and banks and ATMs factor is the least important.

\section{CONCLUSION AND RECOMMENDATIONS}

In this study, one of the Total Quality Management tools, Quality Function Deployment technique is utilized in order to determine quality dimensions of higher education from the stand point of students, student families, academic and administrative staff who consists internal and external customers of higher education. As a result of the analysis based on a survey conducted in a university in Konya, Turkey, three quality dimensions of higher education are identified and measured as physical, academic and access qualification. The results have both importance and perception level of stakeholder groups for the three higher educational quality dimension.

As the results show, there is no significant difference between four stakeholder groups-students, student families, academic staff and administrative staff. Nevertheless, student families have the highest importance level score for all three quality dimensions. Also, academic qualification is considered to be most important quality dimension by the stakeholders.

For the purpose of advancing higher educational quality and consequently ensuring internal and external customer satisfaction, the factors of academic staff qualification, timeliness of curriculum, appropriateness of curriculum for professional career, labs and library qualification, automation system and student affairs are found to be considered as most important for stakeholders.

Reducing factors to more specific and narrower subtitles will help focusing voice of customer more for quality improvement studies in the field of higher education.

\section{REFERENCES}

[1] F. Yenginol, "Neden kalite fonksiyon göçerimi?” Dokuz Eylül İşletme Fakültesi Dergisi, vol. 1, pp. 7-15, 2008.

[2] R. E. Zultner, "TQM for technical teams," Communications of the ACM, vol. 36, pp. 79-91, October 1993.

[3] Y. Akao, "Development history of quality function deployment," The Customer Driven Approach to Quality Planning and Deployment, Japan: Asian Productivity Organization, 1994, p. 339.

[4] Y. Akao, Quality Function Deployment QFD, Integrating Customer Requirements into Product Design, Portland, Oregon: Productivity Press, 1988, p. 17.

[5] Y. Akao, "QFD: Past, present, and future," International Symposium on QFD '97, Linköping, Sweden, 1997.

[6] L. A. Gargione, "Using quality function deployment (QFD) in the design phase of an apartment construction project," in Proc. IGLC-7,
Seventh Conference of the International Group for Lean Construction, University of California, Berkeley, California, USA, 26 - 28 July 1999 , pp. 357-368

[7] A. Akbaba, "Müşteri odakli hizmet Üretiminde kalite fonksiyon göçerimi (KFG) yaklaşimi: Konaklama işletmeleri için bir uygulama çalişmasi," Anatolia: Turizm Araşstırmaları Dergisi, vol. 16, 2005, pp. 59-81.

[8] A. Akbaba, "Yeni ürün geliștirme sürecinde kalite fonksiyon göçerimi (KFG): Turizm işletmeleri için KFG temelli bir ürün geliştirme süreci önerisi," Selçuk Üniversitesi Karaman İktisadi ve İdari Bilimler Dergisi, vol. 2, 2005, pp. 38-59.

[9] E. S. Jaiswal, "A case study on quality function deployment (QFD)," IOSR Journal of Mechanical and Civil Engineering (IOSR-JMCE), vol. 3, November-December 2012, pp. 27-35.

[10] G. Mazur, "QFD for service industries: From voice of customer to task deployment," presented at the Fifth Symposium on Quality Function Deployment, Novi, Michigan, June, 1993.

[11] A. Shahin. (2008). Quality function deployment (QFD): A comprehensive review. [Online]. Available: http://www.researchgate.net/publication/228360297

[12] C. Govers. "QFD not just a tool but a way of quality management," International Journal of Production Economics, vol. 69, 2001, pp. $151-159$

[13] K. Kutucuoglu, J. Hamali, Z. Irani, and J. Sharp, "A framework for managing maintenance using performance measurement systems," International Journal of Operations and Production Management, vol. 2001, pp. 173-195.

[14] B. Kılıç and D. Babat, "Kalite fonksiyon göçerimi: Yiyecek içecek işletmelerine yönelik kuramsal bir yaklaşım," KMÜ Sosyal ve Ekonomik Araştırmalar Dergisi, vol. 13, 2001, pp. 93-104.

[15] J. Hauser and D. Clausing, "The house of quality," Harvard Business Review, vol. 3, 1993, pp. 63-73.

[16] S. Alpaykut, "Kalite fonksiyon göçerimi'nde müşteri sesinin belirlenmesinde yapısal eşitlik modelinin kullanılması," Dokuz Eylül Üniversitesi Sosyal Bilimler Enstitüsü Dergisi, vol. 16, no. 1, 2014, pp. 11-22.

[17] Z. Öter and Ö. Tütüncü, "Turizm işletmelerinde kalite fonksiyon göçerimi: Seyahat acentelerine yönelik varsayımsal bir yaklaşım," Dokuz Eylül Üniversitesi Sosyal Bilimler Enstitüsü Dergisi, vol. 3, no. 3, 2001, pp. 95-117.

[18] E. Güllü, and Y. Ulcay, "Kalite fonksiyonu yayılımı ve bir uygulama," Uludağ Üniversitesi Mühendislik-Mimarllk Fakültesi Dergisi, vol. 7, no. 1, 2002, pp. 71-91.

[19] H. Abdul-Rahman, C. Kwan, and P. Woods, "Quality function deployment in construction design: application in low-cost housing design," International Journal of Quality and Reliability Management, vol. 16, 1999, pp. 591-605.

[20] E. Çavdar and O. Ece. (2010). Eğitimde kalite unsurlarının kalite fonksiyon yayılımı ile belirlenmesi ve bir uygulama. [Online]. Available: http://www.mevzuatdergisi.com/2010/05a/03.htm

[21] S. Çinpolat, "Kalite fonksiyon göçerimi ve hizmet sektöründe uygulanması," M.S. thesis, Institute of Social Sciences, Istanbul Univ., Istanbul, Turkey, 2012

[22] Hacettepe University Strategic Plan. [Online]. Available: https://www.hacettepe.edu.tr/hakkinda/hu20132017sp.pdf

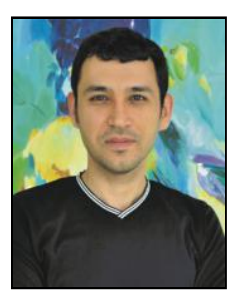

Mehmet A. Gündüz was born in Konya, Turkey, in 1982. He finished his bachelor's degree in management engineering from Istanbul Technical University, Istanbul, Turkey in 2008 . He is currently a $\mathrm{PhD}$ candidate in business administration at Hacettepe Universit At present he is a research assistant at the Department of International Trade, KTO Karatay University, Konya, Turkey from 2010. His research interests are international trade, competitive intelligence and marketing strategies.

Mr. Gündüz is a member of Association of International Marketing Academy.y, Ankara, Turkey. 